\title{
EFFECT OF SOME ESSENTIAL OILS ON SEED GERMINATION AND SEEDLING LENGTH OF Parthenium hysterophorous L.
}

\author{
V.R. Paudel and V.N.P. Gupta* \\ Central Department of Botany \\ Tribhuvan University, Kirtipur, Kathmandu
}

\begin{abstract}
Effect of plant essential oils on seed germination and seedling growth of Parthenium hysterophorus was examined. Essential oils of Eucalyptus, Camphor, and Lemongrass were used in the experiments at different concentrations ( 0 to $20 \mathrm{ml}^{-1} \mathrm{l}^{-1}$ ). Water imbibed $\left(36 \mathrm{~h}\right.$ ) seeds were germinated at $25^{\circ} \mathrm{C} \pm 1$ in petriplates containing 3 layers of filter papers soaked in distilled water and added with $1.5 \mathrm{ml}$ of a given essential oil of particular concentration. Experiments were carried out taking three replicas. Observations were made at an interval of $24 \mathrm{~h}$ from the $4^{\text {th }}$ day of incubation till $20^{\text {th }}$. All essential oils significantly $(\mathrm{P}<0.05)$ reduced seed germination irrespective of their sources. Effects of plant sources were, however, not significant $(\mathrm{P}>0.05)$.
\end{abstract}

Key words: Noxious weed, terpenes, sesquiterpenes, essential oil.

\section{INTRODUCTION}

Parthenium hysterophorus L., family Asteraceae, a noxious weed has infested both fallow and cultivated lands in tropical Asia, North America, etc. Its occurrence was first reported in Nepal in 1982 by Hara et al. (Tiwari et al. 2005). The weed is now widely distributed in a number of tropical and subtropical countries like, Australia, India, China, and Kenya (Navie et al. 1996, Anonymous 2004). This weed has prolific seed production (Haseler 1976), allelopathic effect on neighbouring plants (Adkins and Sowrby 1996), and strong competitiveness with crop plants (Tamado et al. 2002). It has been found toxic to human as well as cattle. Some of the reports revealed that regular contact with the plant or its pollen may cause dermatitis, hay fever and asthma to human beings (Anonymous 2004). It is also reported to have adverse effects to livestock and cattle and even can cause death if consumed in significant amount (Anonymous 2003). A comprehensive account on its phenology has been reported in the pest series publication of Queensland government and the Natural heritage trust, Australia (Anonymous 2003; 2004). The plant contains 'Parthenin', an active chemical which is a terpenoid (sesquiterpene). This group of chemicals are reported to affect the early growth and physiology of Ageratum conizoides (Singh et al. 2005). An allelopathic influence of Parthenium hysterophorus on the early growth of Brassica species by releasing water soluble phenolics into the soil (Batish et al. 2005) and seed germination and seedling growth of Eragrostis tef (Tefera 
2002) have been reported. So far the control of this weed is concerned; an effective control is yet to be achieved through various chemical, biological, or physical methods. Although environment unfriendly and hazardous, the chemical methods involving the use of synthetic herbicides have been tried with limited success elsewhere (Anonymous 2004). As alternative the use of bio-herbicides is considered potential.

Essential oils of aromatic plants are being explored to find out possible herbicides since they do not persist in soil or contaminate ground water and causes little or no mammalian toxicity (Isman 2000). The essential oils can also be used as viable weed control technology under organic farming systems (Tworkoski 2002). The present work addresses the seed germination and early seedling growth of Parthenium hysterophorus in relation to the effects of plant essential oils obtained from common plant species like Lemon grass (Cymbopogon citratus), Eucalyptus (Eucalyptus citrodora), and Camphor (Cinnamomum camphora).

\section{MATERIALS AND METHODS}

Harvesting of seeds: Seeds of Parthenium hysterophorus L. were collected from Kirtipur during August and dried in shade for about a week. Air dried seeds with moisture content below $12 \%$, as managed through repeated weighing and drying, was taken for use in the experiments.

Essential Oils: Extraction of essential oils from Cymbopogon citratus, Eucalyptus citrodora and Cinnamomum camphora leaves was carried out by Clevenger Apparatus. Fresh leaves were shade dried for two days. For a given species of plant, 50 $\mathrm{g}$ of leaves was steam extracted using $500 \mathrm{ml}$ flask.
Three to five hours were allowed for the extraction of oil in one run. Thus, obtained oils were placed in plastic vials and stored at low temperature $\left(10^{\circ} \mathrm{C}\right)$ until used. Acetone $(80 \%)$ was used for each oil to prepare stock solutions and their dilutions to appropriate concentrations ranging from 0 to $20 \mathrm{ml} \mathrm{l}^{-1}$.

Treatments: Seeds were imbibed in distilled water for a period of $36 \mathrm{~h}$. Three layers of filter paper were stacked in all petriplates and moistened by 3 $\mathrm{ml}$ distilled water. Then $1.5 \mathrm{ml}$ oil of desirable concentration was poured on the filter paper and allowed to diffuse by covering the plates. Each of the treatment combination had three replications. Twenty seeds were kept in each plate maintaining equidistance. Plates were incubated at $25 \pm 1^{\circ} \mathrm{C}$. The petriplates were examined for germination regularly.

Statistical analysis: A factorial design was adopted and $f$ - distribution (ANOVA) analysis was carried out to find out the level of significance. The degree of probability $(\mathrm{P}<0.05$ or $\mathrm{P}>0.05)$ has been incorporated into figures.

\section{RESULTS AND DISCUSSION}

The overall study suggests that the essential oils from aromatic plants at their different concentrations have adverse effects on the seed germination and seedling length of Parthenium weed at varying degree. These oils are found perfect to arrest the seed germination of the weed in laboratory condition. Possible effects of plant essential oils on the seed germination and seedling growth of this weed is shown in Fig. $2 a$ and $2 b$. Herbicidal activities of volatile oils of Eucalyptus citriodora against Parthenium hysterophorus L. has been reported recently by Singh et al. (2005). 

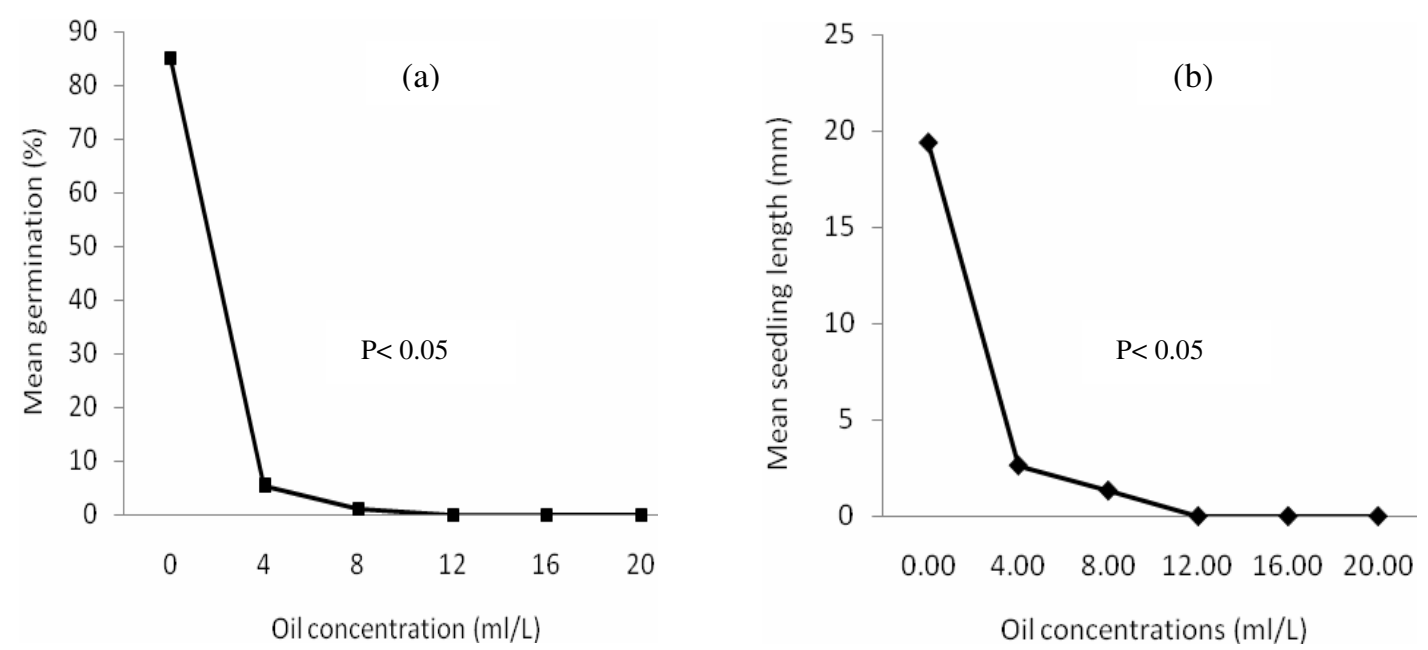

Fig. 1. Effect of essential oils on seed germination (a) and seedling length (b).
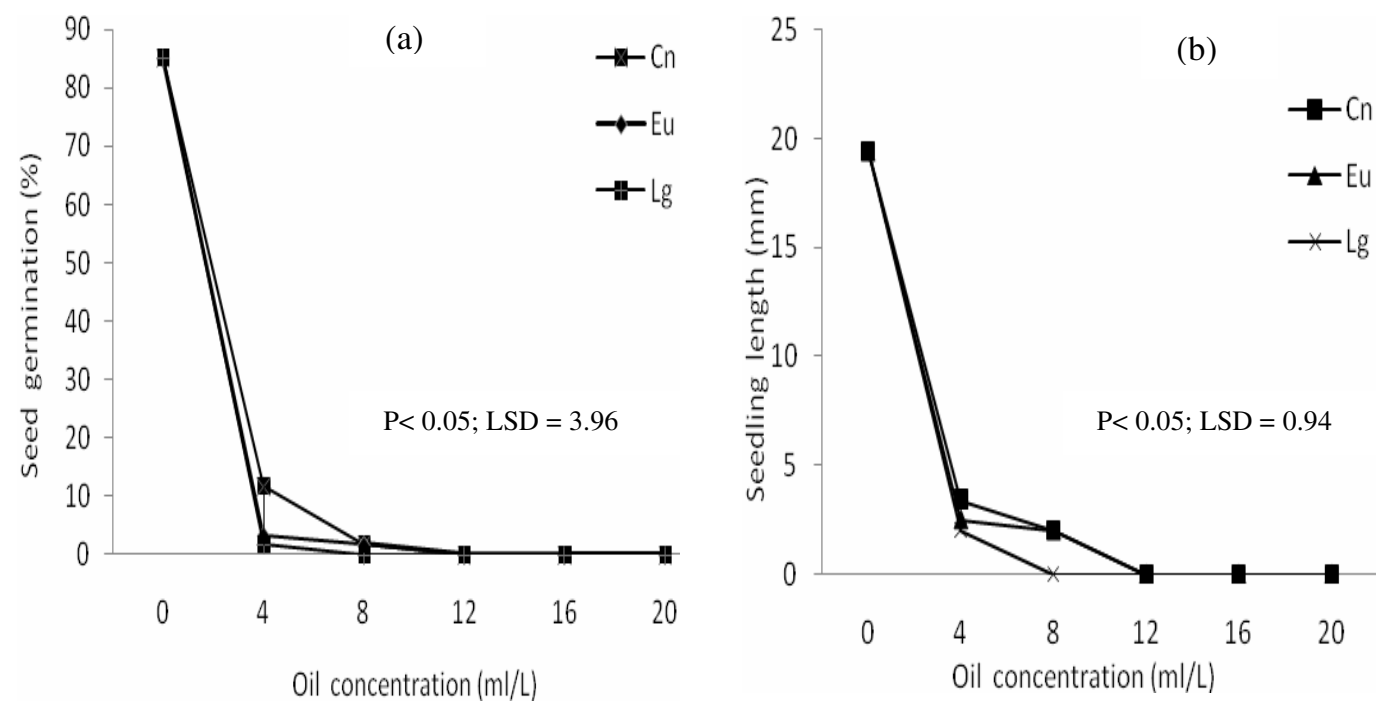

Fig. 2. Individual effects of various concentrations of essential oils on seed germination (a) and seedling length (b) $(\mathrm{Cn}=$ Camphor, Eu = Eucalyptus, Lg = Lemongrass $)$.

Table 1. $f$-distribution (ANOVA) table for Parthenium seed germination.

\begin{tabular}{|l|c|c|c|c|}
\hline Source of variation & Sum of square & Degree of freedom & Mean square & Variance ratio \\
\hline Total & 17628.96 & 17 & - & $-*$ \\
Treatment & 17569.66 & 5 & 3513.93 & $742.9 * *$ \\
Plants & 12.05 & 2 & 6.025 & $1.27 \#$ \\
Error (Residual) & 47.25 & 10 & 4.73 & - \\
\multicolumn{1}{|c|}{ Mean square } & & & & \\
\hline
\end{tabular}

$* *=$ Significant at $\mathrm{p}<0.05, \#=$ Not significant at $\mathrm{p}=0.05$. 
Table 2. $f$-distribution (ANOVA) table for Parthenium seedling length.

\begin{tabular}{|c|c|c|c|c|}
\hline Source of variation & Sum of square & Degree of freedom & Mean square & Variance ratio \\
\hline Total & 884.93 & 17 & - & - \\
\hline Treatment & 881.21 & 5 & 176.24 & $660.07 * *$ \\
\hline Plants & 1.05 & 2 & 0.525 & $1.966 \#$ \\
\hline Error (Residual) & 2.67 & 10 & 0.267 & - \\
\hline Mean square & & & & \\
\hline
\end{tabular}

$* *=$ Significant at $\mathrm{p}<0.05, \#=$ Not significant at $\mathrm{p}=0.05$.

All essential oils significantly $(\mathrm{P}<0.05)$ affected seed germination irrespective to differences in their sources. Effects of plant sources were, however, not significant $(\mathrm{P}>0.05)$. Lemon grass at $8 \mathrm{ml} \mathrm{l}^{-1}$, Cinnamomum and Eucalyptus oil, each at $12 \mathrm{ml} \mathrm{l}^{-1}$ inhibited the germination of Parthenium seeds completely (Fig. $2 \mathrm{a})$. In the case of Cinnamomum oil, only $11.67 \%$ and $1.67 \%$ seeds germinated at $4 \mathrm{ml} \mathrm{l}^{-1}$ and $8 \mathrm{ml} \mathrm{l}^{-1}$ concentrations, respectively. None of the seeds, however, germinated at and above $12 \mathrm{ml} \mathrm{l}^{-1}$ concentrations of any of the oils. Concentration responses were found as $20 \mathrm{ml} \mathrm{l}^{-1}=16 \mathrm{ml} \mathrm{l}^{-1}=12$ $\mathrm{ml} \mathrm{l}^{-1}>8 \mathrm{ml} \mathrm{l}^{-1}>4 \mathrm{ml} \mathrm{l}^{-1}(\mathrm{P}<0.05 ; \mathrm{LSD}=3.96)$.

Similarly all essential oils significantly $(\mathrm{P}<0.05)$ affected seedling lengths of Parthenium hysterophorus. Oil concentrations at $4 \mathrm{ml} \mathrm{l}^{-1}$ of Lemon grass, $8 \mathrm{ml} \mathrm{l}^{-1}$ of Cinnamomum and $8 \mathrm{ml} \mathrm{l}^{-}$ ${ }^{1}$ of Eucalyptus showed similar values for seedling length. The Concentration responses were found as $20 \mathrm{ml} \mathrm{l}^{-1}=16 \mathrm{ml} \mathrm{l}^{-1}=12 \mathrm{ml} \mathrm{l}^{-1}>8 \mathrm{ml} \mathrm{l}^{-1}>4 \mathrm{ml} \mathrm{l}^{-1}$ $(\mathrm{P}<0.05 ; \mathrm{LSD}=0.94)$ as shown in Fig. $2 \mathrm{~b}$.

Our results may be interpreted in terms of different kinds of terpenoids present in plant essential oils and their probable effects on seed germination process. It is reported that these terpenoids, particularly the sesquiterpene, is a group of compounds with variable biological activities. Active at low concentrations these compounds exhibit specific structure-activity relationship (Beekman et al. 1997). Among several biologically active compounds, the phytotoxic potential of sesquiterpene lactones has long been established (Dalvi et al. 1971, Dayan et al. 1999). Possible roles of these terpenes in regulating hydrolytic enzymes including amylases, de novo synthesized in germinating seeds, can not be overruled. Works in the line of further chemical characterization of the used essential oils are speculated to justify the finding of the present investigation.

\section{REFERENCES}

Adkins, S.W. and M.S. Sowerby. 1996. Allelopathic potential of the weed, Parthenium hysterophorus L. in Australia. Plant Protection (Qtr.) 11:20-23.

Annonymous. 2004. Parthenium weed (P. hysterophorus), Pest series, Dept. of Natural Resources and Mines, Queensland, Australia, QNRMO 1219, pp. 2-4.

Anonymous. 2003. Weed Management Guide. Parthenium weed (P. hysterophorus). Natural Heritage Trust, Australia, pp. 1-6.

Batish, D.R., H.P. Sing, D.B. Saxena, R.K. Kohli and V. Arrora. 2002. Effect of Parthenin-a sesquiterpene lactone from Parthenium hysterophorus, on early growth and physiology of Ageratum conizoides. Journal of Chemical Ecology 28:2169-2179.

Batish, D.R., H.P. Sing, J.K. Pandher and R.K. Kohli. 2005. Phytotoxic effect of Parthenium hysterophorus residues on three Brassica 
species. Weed Biology and Management 5:105-109.

Beekman, A.C., H.J. Woerdenbag, W.V. Uden, N. Pras, Wikstroemtiv and T.J. Schmidt. 1997. Structure-cytotoxicity relationship of some Phelenanolide-type Sesquiterpene lactones. Journal of Natural Products 60:252-257.

Dalvi, R.R., B. Singh and D.K. Salunkhe. 1971. A study on phytotoxicity of Alantolactones. Chem. Biol. Interact 3:13-18.

Dayan, F.E., A. Hernandez, S.N. Allen, R.M. Moraes, J.A. Vroman, M.A. Avery and S.O. Dukes. 1999. Comparative phytotoxicity of artemisinin and several sesquiterpenes analogues. Phytochemistry 50:15-24.

Haseler, W.H. 1976. Parthenium hysterophorus L. in Australia. Pest Articles and News Summaries (PANS) 22:515-517.

Isman, M.B. 2000. Plant essential oils for pest and disease management. Crop Protection 19:603608 .

Navie, S.C., R.E. Mc. Fadyen, F.D. Panetta and S.W. Adkins. 1996. The biology of Australian weeds. Parthenium hysterophorus L. Plant Protection (Qtr.). 11:76-88.

Singh, H.P., D.R. Batish, N. Setia and R.K. Kohli. 2005. Herbicidal activity of volatile oil from Eucalyptus citrodora against $P$. hysterophorus. Annals of Applied Biology 146:89-94.

Tamado, T., W. Schutz and P. Milberg. 2002. Germination ecology of the weed Parthenium hysterophorus L. in eastern Ethiopia. Annals of Applied Biology 140:263-270.

Tefera, T. 2002. Allelopathic effects of Parthenium hysterophorus extracts on seed germination and seedling growth of Eragrostis tef. J. Agronomy and Crop Science 188:306310 .

Tiwari, S., V. Adhikari, M. Siwakoti and K. Subedi. 2005. An Inventory and Assessment of Invasive Alien Plant Species of Nepal. IUCN Nepal, 115 pp.

Tworkoski, T. 2002. Herbicide effects of essential oils. Weed Science 50:425-431. 